\section{Optimum conditions for seed propagation of Garcinia brasiliensis: mimicking natural habitats allows better results}

\author{
Amanda A. Cardoso ${ }^{1 *}$ (D), Sandro Barbosa ${ }^{1}$ (D) Breno R. Santos ${ }^{1}$
}

ABSTRACT: Garcinia brasiliensis is a tropical tree species of economic importance to local populations in the Amazon and Atlantic forests. The plant propagation of this species occurs mostly through seeds and despite that very little information about seedling emergence and growth is currently available. Here we assessed basic information on the seed and seedling ecophysiology of G. brasiliensis aiming at providing key details for seed propagation. Seeds are large and contain high levels of water when recently collected (c. 50\%). Seed storage, especially under low temperature, resulted in very low seedling emergence. Fruit storage at c. $25{ }^{\circ} \mathrm{C}$, on the other hand, was demonstrated to be the best option for maintaining seed viability in the short term. Removal of the seed coat considerably hastened and increased the percentage emergence of seedlings, despite the light condition. Similarly, a higher percentage and index of seedling emergence was observed under $35^{\circ} \mathrm{C}$ over $25^{\circ} \mathrm{C}$, despite the substrate. Amongst all the substrates tested, sand resulted in lower seedling emergence. Cultivating seedlings in vermiculate and at $25^{\circ} \mathrm{C}$ provided the best condition for root and shoot growth. Ideal conditions of light and temperature for seedling emergence and development mirror the environmental conditions under which plants of $G$. brasiliensis establish in nature.

Index terms: Clusiaceae, plant establishment, plant growth, seed germination, tropical evergreen species.

\section{Condições ótimas para a propagação de sementes de Garcinia brasiliensis: simulação de habitats naturais permite melhores resultados}

RESUMO: Garcinia brasiliensis é uma espécie arbórea tropical de grande importância econômica para populações locais das Florestas Amazônica e Atlântica. A propagação se dá majoritariamente por sementes, e ainda sim, pouca informação sobre a emergência e crescimento de sua plântula é encontrada. Nesse trabalho, nós estudamos informações básicas acerca da ecofisiologia da semente e das plântulas a fim de promover conhecimento para propagação dessa espécie via semente. As sementes são grandes e com alto teor de água (c. $50 \%$ ). $O$ armazenamento de sementes, especialmente sob baixas temperaturas, resultou em baixas taxas de emergência. $\mathrm{O}$ armazenamento de frutos a $25^{\circ} \mathrm{C}$, por outro lado, se mostrou como a melhor opção para o armazenamento no curto prazo. A remoção do tegumento aumentou e acelerou a emergência de plântulas, independente da luz. Similarmente, maior porcentagem e index de emergência foram observados a $35^{\circ} \mathrm{C}$, independente do substrato. Dentro os substratos avaliados, areia resultou em menor emergência. $O$ cultivo em vermiculita a $25{ }^{\circ} \mathrm{C}$ foi melhor para o crescimento da raiz e da parte aérea. As condições ideias de luz e temperatura para emergência e crescimento de plântulas de $G$. brasiliensis refletem as condições ambientais naturais nas quais essa espécie é encontrada.

Termos para indexação: Clusiaceae, crescimento vegetal, espécie tropical perene, estabelecimento vegetal, germinação de sementes.
Journal of Seed Science, v.43, e202143014, 2021

http://dx.doi.org/10.1590/ 2317-1545v43248633
$*$ Corresponding author
E-mail: amanda.cardoso@unifal-mg.edu.br

Received: 2/10/2021. Accepted: 5/20/2021.

${ }^{1}$ Instituto de Ciências da Natureza, Universidade Federal de Alfenas Alfenas, Minas Gerais, Brasil. 


\section{INTRODUCTION}

Garcinia brasiliensis Mart. (Clusiaceae), commonly-known in Brazil as bacupari, is an evergreen tree species occurring in the Amazon and Atlantic forests of Brazil (Leal et al., 2013), species-rich biomes endangered due to deforestation (Myers et al., 2000). Most plants of $G$. brasiliensis grow wild and semi-wild in forests, constituting an important source of valuable pharmaceutical compounds to local populations in Brazil. The leaves and fruits contain numerous compounds, such as benzophenones and phenolic constituents, which were demonstrated to have anti-inflammatory and antioxidant properties (Gontijo et al., 2012; Arwa et al., 2015) as well as anticancer potential (Sales et al., 2015). Plant propagation occurs mostly through seeds and despite that, basic information on seed and seedling ecophysiology remains to be investigated. Such information is crucial for the development of suitable ex situ conservation strategies (Malik et al., 2005) and for providing an efficient protocol for plant production, avoiding forest overexploitation.

Alike other Garcinia species (Malik et al., 2005; Joshi et al., 2006), anatomical analysis of G. brasiliensis seeds reveal that seeds are comprised of a large hypocotyl-radicle axis surrounded by the seed coat. They also exhibit rudimentary cotyledons (formed by a few cells) and no endosperm is observed in mature seeds (Cardoso et al., 2013). Seed reserves, which are mostly composed of large starch grains, are stored in the large hypocotyl-radicle axis (Cardoso et al., 2013). Regarding seed germination, only two studies have examined the seed germination for $G$. brasiliensis to date and both of them describe it as a slow process likely due to the physical dormancy imposed by the seed coat (Zamith and Scarano, 2004; Oliveira and Nunes, 2013). None of these studies assessed whether the seed coat imposes impermeability (i.e. physical dormancy) or mechanical restrictions to the germination of this species, however, the seed coat of other Garcinia species has been demonstrated to impose physical dormancy on the seeds (Viana et al., 2020).

Although seeds of $G$. brasiliensis were demonstrated to be dormant, they have also been shown to be recalcitrant (Oliveira and Nunes, 2013), resulting in an intriguing combination of dormancy and recalcitrancy, which is characteristic of this genus (Viana et al., 2020), but very rare in nature (Tweddle et al., 2003).

In the natural environment, seed germination and subsequent early seedling growth typically occur close to the mother plants under low light conditions (Correia et al., 2013). Further studies on G. brasiliensis have identified this species as shade-tolerant mid-late successional, meaning that it establishes in the understory (Lucas et al., 2012). Both observations lead us to hypothesize that seedlings of $G$. brasiliensis would benefit from low light intensity conditions during emergence and establishment, thus representing the best condition for plant propagation. Given the relatively high temperatures frequently observed in the sites of occurrence of $G$. brasiliensis [mean annual temperature ranging from c. 21 to $33^{\circ} \mathrm{C}$ in the Amazon forest (Moser et al., 2019) and from c. 15 to $35^{\circ} \mathrm{C}$ in the tropical sites of the Atlantic forest (Vitória et al., 2019)], we would also suggest that high temperatures are well tolerated by this species.

Despite the utmost importance of $G$. brasiliensis to Brazilian biomes and local communities and that the plant propagation is mostly performed through seeds, no information about the best conditions for seed germination and plant growth is currently available in the literature. Therefore, in this study, we unravel for the first time in our knowledge basic information about the seeds and the potential for seed storage as well as the effects of light, temperature, substrate and the presence or absence of seed coat on seedling emergence and growth of $G$. brasiliensis. Specifically, we characterized (i) the seeds and seedlings characteristics, (ii) the potential storage of fruits and seeds in the short term, and (iii) the effects of mechanical scarification, light, substrate, and temperature on the emergence and growth of seedlings. The results were discussed in terms of plant production and ecology.

\section{MATERIAL AND METHODS}

\section{Seed collection and characteristics}

Fruits of G. brasiliensis were collected during summer from natural populations in Viçosa ( $20^{\circ} 45^{\prime} 14^{\prime \prime}$ ' S; 42 $52^{\prime} 55^{\prime \prime}$ $\mathrm{O}, 650 \mathrm{~m}$ above sea level), Brazil. The site is characterized by a subtropical climate, with a mean annual temperature 
of $20^{\circ} \mathrm{C}$ and rainfall of $1200 \mathrm{~mm}$. Seeds were extracted from the fruits and had their surface sterilized in $50 \%$ sodium hypochlorite for ten minutes. Seed characteristics were determined immediately after seed collection. Length, width and weight were determined for fifty fresh seeds, while four replicates of fifty seeds were dried in an oven at $105 \pm 3{ }^{\circ} \mathrm{C}$ until weights were stable (c. $36 \mathrm{~h}$ ) to assess seed water content.

\section{Storage of seeds and fruits}

Seeds were stored in paper bags at $5{ }^{\circ} \mathrm{C}$ and $25 \pm 5{ }^{\circ} \mathrm{C}$ (Pereira et al., 2016), while fruits were stored in woven polypropylene bags at $25 \pm 5{ }^{\circ} \mathrm{C}$. Seeds and fruits were maintained under these conditions for 150 days. Next, seeds were surface sterilized as described above, sown in plastic trays containing sterilized vermiculite, and daily irrigated with distilled water until full soil capacity. The trays were placed in a BOD-type chamber (Novatecnica, Brazil) at $25 \pm 1{ }^{\circ} \mathrm{C}$ and under continuous light [photosynthetic photon flux density (PPFD) of $50 \mu \mathrm{mol} \mathrm{m}^{-2} . \mathrm{s}^{-1}$ at the seed level]. During ninety days, the seedling emergence was daily monitored and the final percentage of seedling emergence and the emergence speed index (EI) were calculated (Maguire, 1962). Data obtained after storage were contrasted with data obtained with newly collected seeds (i.e. seeds that haven't been stored). The experiment was conducted in a completely randomized design and it was composed of five replicates of twenty seeds per treatment.

\section{Seedling emergence}

Seedling emergence assays were initiated immediately after seed collection. Part of the seeds underwent a scarification pretreatment at which the seed coats were carefully removed by hand (i.e. decoated seeds), while the remaining seeds were maintained with their coat intact (i.e. coated seeds). Both coated and decoated seeds were sown in plastic trays filled with sterilized vermiculite and daily irrigated with distilled water to full soil capacity. The trays were placed in BOD-type chambers at $25 \pm 1{ }^{\circ} \mathrm{C}$ and under three light conditions, i.e. 0:24 h light/dark (dark), 12:12 h light/dark or 24:0 h light/dark (light). The PPFD was $50 \mu \mathrm{mol} \mathrm{m}{ }^{-2} . \mathrm{s}^{-1}$ at the seed level. Seed emergence under dark was assessed by using green light. During ninety days, the seedling emergence was daily monitored and the final percentage of seedling emergence and the El were calculated (Maguire, 1962). The experiment was conducted in a $2 \times$ 3 factorial design with five replicates of twenty seeds per treatment.

A second experiment was performed based on results from the first experiment. Decoated seeds were sown in plastic trays containing three different substrates, i.e. sand, sand + vermiculite $(1: 1 ; \mathrm{v}: \mathrm{v})$ and vermiculite. All substrates have been previously autoclave-sterilized. Seeds were daily irrigated to full soil capacity and the trays were placed in BOD-type chambers under continuous light (PPFD of $50 \mu \mathrm{mol} \mathrm{m} \mathrm{m}^{-2} \cdot \mathrm{s}^{-1}$ at seed level) and the temperature was controlled either at $25 \pm 1{ }^{\circ} \mathrm{C}$ or $35 \pm 1{ }^{\circ} \mathrm{C}$. During ninety days, the seedling emergence was daily monitored and the final percentage of seedling emergence and the El were calculated (Maguire, 1962). The experiment was conducted in a $3 \times 2$ factorial design with five replicates of twenty seeds per treatment.

\section{Seedling growth}

The effects of light [12:12 h light/dark and 24:0 h light/dark (light)], substrate [sand, sand + vermiculite (1:1; v:v), and vermiculite] and temperature $\left(25\right.$ and $\left.35{ }^{\circ} \mathrm{C}\right)$ on the seedling growth were assessed (Cardoso et al., 2015). To test the effect of the light condition, seeds were sown in plastic trays filled with vermiculite and irrigated daily with distilled water to full soil capacity. The trays were placed in BOD-type chambers at $25 \pm 1{ }^{\circ} \mathrm{C}$ under $12: 12 \mathrm{~h}$ light/dark or $24: 0 \mathrm{~h}$ light/dark (light) (PPFD of $50 \mu \mathrm{mol} \mathrm{m}{ }^{-2} . \mathrm{s}^{-1}$ at seed level). To test the effect of the substrate condition, seeds were sown in plastic trays filled with each substrate and moistened daily with distilled water until full capacity. The trays were placed in a BOD-type chamber at $25 \pm 1{ }^{\circ} \mathrm{C}$ under continuous light (PPFD of $50 \mu \mathrm{mol} \mathrm{m}{ }^{-2} \cdot \mathrm{s}^{-1}$ at seed level). To test the effect of the temperature condition, seeds were sown in plastic trays filled with vermiculite and daily irrigated with distilled water to full soil capacity. The trays were placed in a BOD-type chamber under continuous light (PPFD of $50 \mu \mathrm{mol}$ $\mathrm{m}^{-2} \cdot \mathrm{s}^{-1}$ at seed level) and the temperature was controlled at either $25 \pm 1^{\circ} \mathrm{C}$ or $35 \pm 1{ }^{\circ} \mathrm{C}$. The experiments were carried out for c. 105 days (ninety days for seedling emergence and fifteen days for seedling growth). Seedling emergence 
was monitored daily and each newly emerged seedling was tagged. When seedlings were fifteen days old, the length and dry weight of roots and shoots were assessed. The seedling adventitious root rather than the primary root was utilized for this purpose given that it represents the main root for the plant establishment (see discussion below). The experiments were conducted in a completely randomized design with four replicates of five seedlings per treatment.

\section{Statistical analysis}

The data were subjected to tests for normality (Lilliefors) and homoscedasticity (Cochran), followed by an analysis of variance. To test whether each storage condition was similar to the control, i.e. newly collected seeds, data were subjected Dunnett's test at 5\% probability. For the remaining experiments, means were compared by the Scott-Knott test at 5\% probability. The software SISVAR 5.0 (Ferreira, 2011) and SigmaPlot 11.0 (Systat Software Inc., San José, CA, USA) were used for statistical tests and graphical designs.

\section{RESULTS AND DISCUSSION}

The anatomy of G. brasiliensis seeds has previously been demonstrated (Cardoso et al., 2013), and here we examine its morphology and ecophysiology. This study provides for the first time, to the best of our knowledge, a whole picture of seed storage behavior, germination events, and seedling emergence and growth under several environmental conditions for this species. Such basic information on seed and seedling ecophysiology is highly recommended for defining suitable ex situ conservation strategies (Malik et al., 2005) and for domestication and cultivation of wild and semi-wild commercially valuable species such as G. brasiliensis, avoiding the overexploitation of forests.

Seeds of $G$. brasiliensis were large (mean fresh weight of $2.4 \pm 0.4 \mathrm{~g}$, mean length of $2.2 \pm 0.2 \mathrm{~cm}$, and mean breadth of $1.4 \pm 0.1 \mathrm{~cm}$ ), exhibiting light brown seed coat and yellow to light brown embryo. The mean water content for the newly collected seed was as high as $48.6 \pm 0.7 \%$. Germination was initiated by the emergence of a thin primary root from one pole (Figure 1A), followed by the simultaneous emergence of a purple epicotyl and a thick adventitious root from the opposite pole (Figure 1B). The differentiation of primary root and primary shoot (epicotyl) from opposite poles suggests polarity in these seeds exhibiting the two poles (root and shoot poles). The emergence of purple metaphylls (true leaves) was observed within fifteen days (Figure 1C). A similar pattern of seedlings development was found for other seeds yet no emergence of primary root was detected (Figure 1D-F).

Since the first description of seed germination characteristics of Garcinia genus (de Vogel 1980), the "garcinia-type" of germination pattern has been reinforced for a number of Garcinia species originated from India and Brazil, including G. brasiliensis (Nascimento et al., 2002; Malik et al., 2005; Joshi et al., 2006; Correia et al., 2013). Following other studies theory and at odds with Correia et al. (2013), we suggest that the root that emerges in the base of the epicotyl seeds of G. brasiliensis comprises an adventitious root rather than a primary root per se as it develops post-embryonically from shoots (Bellini et al., 2014). This adventitious root is extremely important to the seedling establishment as it takes over as the main root system of the plant instead of the primary root, which disintegrates over six months (Nascimento et al., 2002; Joshi et al., 2006). Besides, the purple color observed in both epicotyls and metaphylls indicates the presence of anthocyanin-derived pigments (Figure 1), which is likely linked to the protection of the photosynthetic apparatus against high light (Nichelmann and Bilger, 2017).

Overall, seed storage, but not fruit storage, promoted differences in emergence parameters (Table 1). Following 150 days of fruit seed storage, seedling emergence percentage and El were similar to those found when seeds from newly collected fruits were planted. Conversely, when seeds were stored, seedling emergence percentage and EI markedly declined when compared with newly collected seeds. Among seed storage conditions, seed storage at $5{ }^{\circ} \mathrm{C}$ was observed to induce the highest reduction in the aforementioned parameters. Together (i) the elevated water content of newly collected seed (as high as c. 50\%), (ii) the relatively short lifespan (consistent declines in seedling emergence percentage after storage; Table 1), and (iii) the marked chilling sensitivity (extremely low seedling emergence percentage after storage at $5^{\circ} \mathrm{C}$; Table 1 ) reinforce $G$. brasiliensis seeds as recalcitrant. 


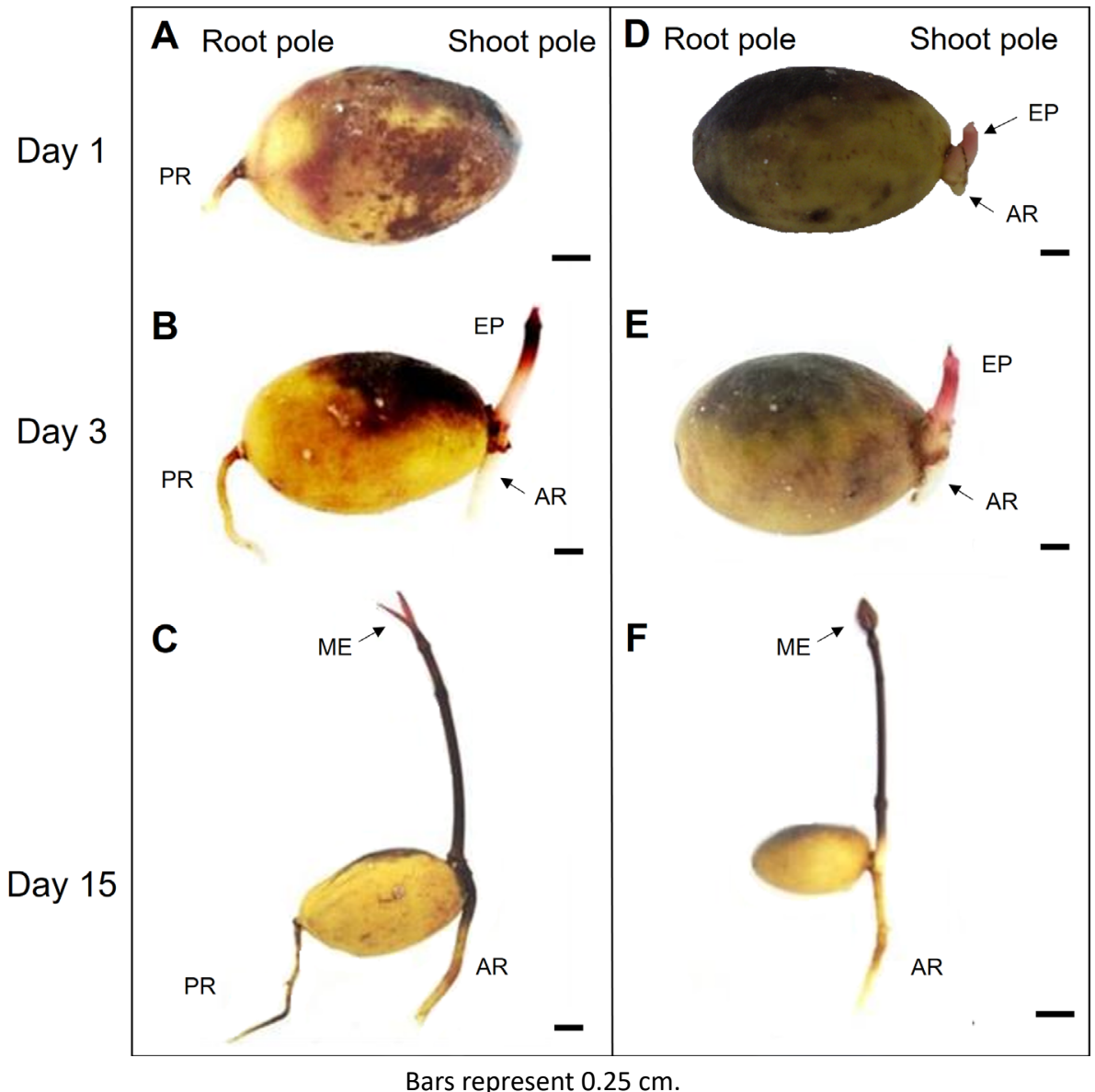

Figure 1. Representative images of Garcinia brasiliensis seedlings during fifteen days after germination. Emergence of primary roots (PR) from the root pole was observed in some seeds $(A-C)$ but not in others (D-F). From the shoot pole, epicotyl (EP) and adventitious roots (AR) emerged in all seeds. Emergence metaphylls (ME) occurred within fifteen days after germination.

Table 1. Seedling emergence (\%) and seedling emergence speed index (EI) for seeds of Garcinia brasiliensis stored at $5{ }^{\circ} \mathrm{C}$ or $25^{\circ} \mathrm{C}$ and fruits stored at $25^{\circ} \mathrm{C}$ for 150 days.

\begin{tabular}{ccc}
\hline Storage condition & Emergence (\%) & El \\
\hline Newly collected seeds & $65 \pm 4.5$ & $0.31 \pm 0.03$ \\
Fruits at $25^{\circ} \mathrm{C}$ & $37 \pm 4.4$ & $0.15 \pm 0.02$ \\
Seeds at $25^{\circ} \mathrm{C}$ & $24 \pm 2.1^{*}$ & $0.07 \pm 0.01^{*}$ \\
Seeds at $05^{\circ} \mathrm{C}$ & $02 \pm 1.2^{*}$ & $0.01 \pm 0.00^{*}$ \\
\hline
\end{tabular}

Data are mean \pm SE $(n=5)$.

*Values followed by asterisk differ from the control (newly collected seeds) at the $5 \%$ level by Dunnett's test.

Several Amazonian forest species, including other Garcinia species, have already been classified as recalcitrant (Liu et al., 2005; Lucas et al., 2012; Oliveira and Nunes, 2013). The ubiquitous feature of recalcitrant seeds is the desiccation sensitivity (Berjak and Pammenter, 2013). Since recalcitrant seeds require high levels of water to retain viability and to improve plant establishment in the environment, recalcitrant seeds must germinate within a short period after shedding. Long periods might drive recalcitrant seeds to desiccation and hence loss of viability. The same 
loss of viability due to desiccation renders long-term storage of recalcitrant seeds, for either ex situ conservation or plant production, highly complex (Berjak and Pammenter, 2013). In this regard, planting seeds as soon as they are collected remains the best option to obtain maximum emergence. If not possible, we demonstrate that fruit storage at around $25^{\circ} \mathrm{C}$ is a simple, low-cost method for efficiently storing seeds of $\mathrm{G}$. brasiliensis for at least 150 days. This simple yet functional method to preserve seed water content and hence viability for longer periods is likely similar to what happens in nature, where seeds remain inside the fruits until fruits are partially damaged or they partially decompose and where fruits are maintained under naturally warm temperatures and elevated humidity (Zamith and Scarano, 2004; Leal et al., 2013).

Regarding, seed emergency, we did not find significance of interactions in the two factorial analyses. Seedling emergence was initiated far earlier in decoated seeds ( 26 days) than in coated seeds ( 38 days). Seedling emergence percentage and El were considerably enhanced in decoated seeds than in coated seeds, under all light conditions. Regarding light, the presence of continuous light increased the $\mathrm{El}$ of decoated seeds, while the 12:12 $\mathrm{h}$ light/dark condition increased seedling emergence percentage and El of coated seeds (Figures $2 \mathrm{~A}-\mathrm{B}$ ). The $35{ }^{\circ} \mathrm{C}$ temperature promoted the highest seedling emergence percentage and $\mathrm{El}$ when compared with $25^{\circ} \mathrm{C}$, for all substrates. Both sand + vermiculite or solely vermiculite were demonstrated to enhance seedling emergence percentage and $\mathrm{EI}$ when compared with sand (Figures $2 \mathrm{C}-\mathrm{D}$ ).

The coated-imposed dormancy observed in this study for $G$. brasiliensis has been also reported for several other Garcinia species (Liu et al., 2005; Joshi et al., 2006; Oliveira and Nunes, 2013, Viana et al., 2020). These studies found that the thick seed coat of Garcinia species (Liu et al., 2005) plays a critical role in delaying germination by restricting permeability to water and oxygen (Viana et al., 2020). Thus, damaging the seed coat has been demonstrated to successfully

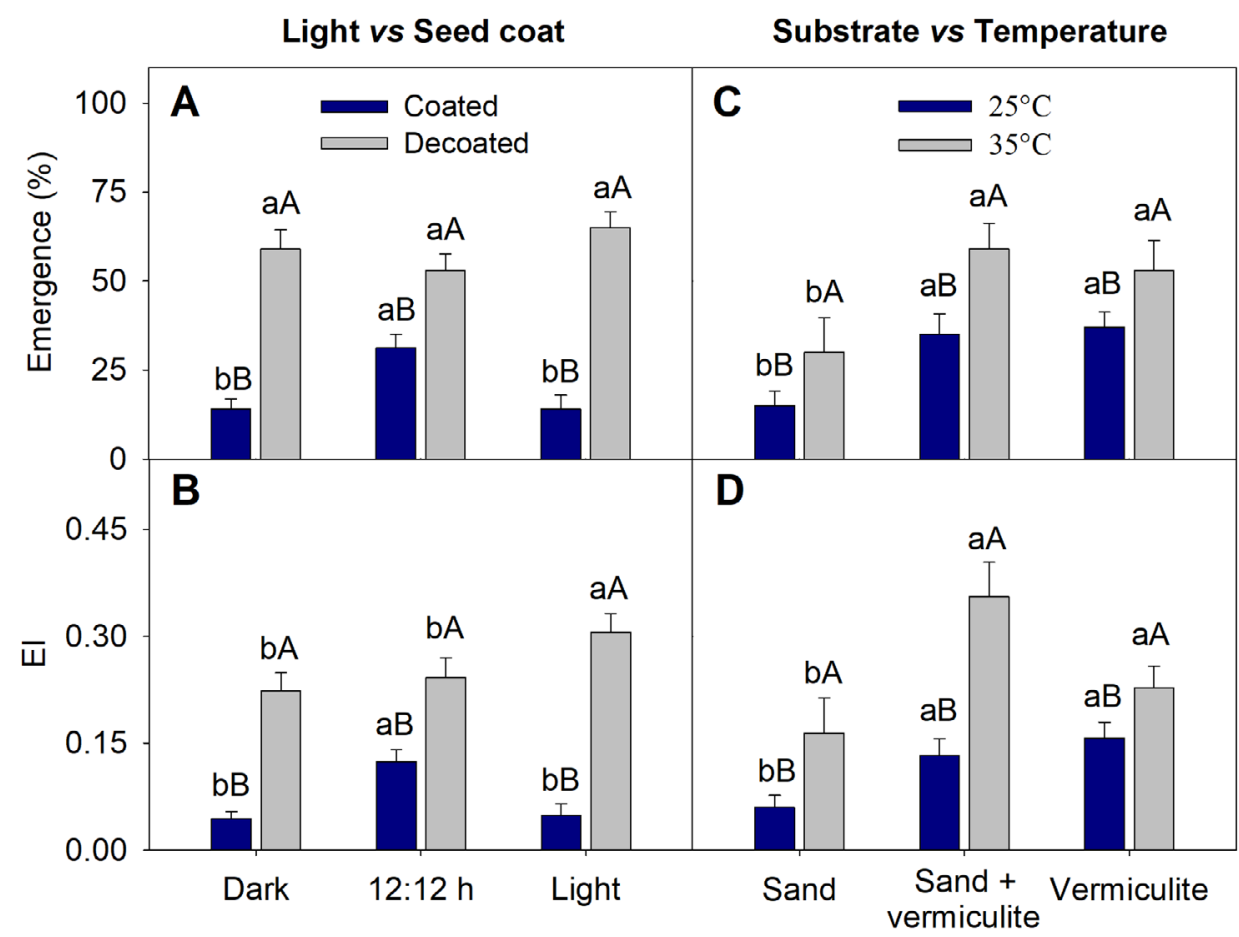

Bars followed by the same small letter across the three conditions of light and substrate or bars followed by the same capital letter across the two conditions of coat and temperature do not differ statistically at the $5 \%$ level by Scott-Knott test. Data are mean \pm SE $(n=5)$.

Figure 2. (A and B) Seedling emergence (\%) and seedling emergence index (EI) for coated and decoated seeds of Garcinia brasiliensis. Emergence tests were conducted under 0:24 h light/dark (dark), 12:12 h light/dark or 24:0 $\mathrm{h}$ light/dark (light). ( $C$ and D) Seedling emergence (\%) and El for coated seeds of G. brasiliensis sown in sand, sand + vermiculite $(1: 1 ; \mathrm{v}: \mathrm{v})$, or vermiculite. Emergence tests were conducted at 25 or $35^{\circ} \mathrm{C}$. 
accelerate seed germination in G. brasiliensis (Oliveira and Nunes, 2013) and here we also found that the simple removal of the seed coat, which can easily be done by hand, can be utilized as a suitable method for plant production of this species (and likely for other Garcinia species), as it successfully enhances and hastens seedling emergence.

After removing the seed coat, the light condition did not influence seed emergence (Figure 2). As G. brasiliensis seeds do not require light for germination to occur, seeds can germinate in open areas, canopy gaps, or in the deep shade of the forest canopy. The only restriction is regarding soil water content for the imbibition process. Seeds can also germinate under a wide range of temperatures (i.e. from 25 to $35^{\circ} \mathrm{C}$ ), yet seed emergence is enhanced under elevated temperatures, such as $35^{\circ} \mathrm{C}$ (Figure 2). Elevated temperatures indeed are commonly found to induce high germination rates in Amazonian species (Brancalion et al., 2010). Further, the higher emergence under elevated temperatures may be part of an ecological strategy of $G$. brasiliensis for seed propagation, as fruit production occurs mainly during spring and early summer when temperatures are typically higher than $30{ }^{\circ} \mathrm{C}$ in the Brazilian Amazon and Atlantic forests (Leal et al., 2013). The wide range of light and temperature conditions for $G$. brasiliensis emergence facilitates plant production of this species, and to enhance seedling emergence, seeds should be maintained at elevated temperatures (c. $35^{\circ} \mathrm{C}$ ) until seedling emergence.

Light conditions (continuous light or 12:12 $\mathrm{h}$ light/dark) did not affect the seedling length and dry weight (Figures $3 A-B)$. Vermiculite allowed both the highest root and shoot length and dry weight compared with the other two substrates (Figures $3 \mathrm{C}-\mathrm{D}$ ). Finally, $25{ }^{\circ} \mathrm{C}$ enhanced both root and shoot development, with the highest values for seedling length and dry weight compared with $35^{\circ} \mathrm{C}$ (Figures $3 \mathrm{E}-\mathrm{F}$ ). Seedling growth was not limited by the light condition as growth under continuous light and 12:12 h light:dark cycle were demonstrated to be similar. However, the higher temperature tested (i.e. $35^{\circ} \mathrm{C}$ ) resulted in an impaired root development when compared with $25^{\circ} \mathrm{C}$ (Figure 2).

In nature, G. brasiliensis seedlings and plants are typically established in shaded environments (Correia et al., 2013), and the species has been considered shade-tolerant mid-late successional (Lucas et al., 2012). Our findings regarding seedling growth under different light and temperature conditions support the shade-tolerance for the species, likely linked to a late-successional status. As lower temperatures are expected in shaded environments, it would be expected that temperatures as lower as $25^{\circ} \mathrm{C}$ would enhance plant establishment. In this regard, elevated temperatures during spring and summer result in increased seedling emergence, and during autumn and winter, it is expected a better seedling development and establishment. For plant production, seedling maintenance under shaded environments is highly encouraged for plant production of this species. We also suggest that both vermiculite and even sand + vermiculite, rather than solely sand, can be utilized as substrates when cultivating G. brasiliensis seedlings for 105 days or less. Sandy soils have been demonstrated to strongly restrict root growth, due to low compressibility and high friction, which offers few low-resistance pathways (Bruun et al., 2014). Here we also observed restriction to shoot growth, likely linked to reduced root growth. In any event, we acknowledge that further studies cultivating $G$. brasiliensis plants for longer periods are necessary to define the best conditions for plant propagation in commercial nurseries.

In summary, here we demonstrate that for the best seedling emergence of $G$. brasiliensis, seeds should be sown as soon as collected, but if necessary, fruits rather than seeds should be stored for short periods (up to 150 days). Although we found in this study that storage of fruits at $25{ }^{\circ} \mathrm{C}$ was beneficial for maintaining higher rates of seed germination, other temperatures should be tested to find whether better ones can be utilized. The coat-imposed reduction in germination can be easily overcome by simply removing the seed coat (resulting in considerably higher germination percentage and El when compared with seeds with coat), which can be easily done by hand. Ideal light and temperature conditions for seedling emergence (continuous light and $35^{\circ} \mathrm{C}$ ) and development (photoperiod of $12 \mathrm{~h}$ and $25^{\circ} \mathrm{C}$ ) mirror environmental conditions under which plants of $\mathrm{G}$. brasiliensis establish in nature, i.e. elevated temperatures for seedling emergence and mild temperatures for seedling development and a wide range of light conditions for seedling emergence and development. We believe, however, that shaded environments might be better suited for plant production, given that this species has been shown to be shade-tolerant and because under shade temperatures are likely to be lower, which improves seedling growth. 


\section{Light}
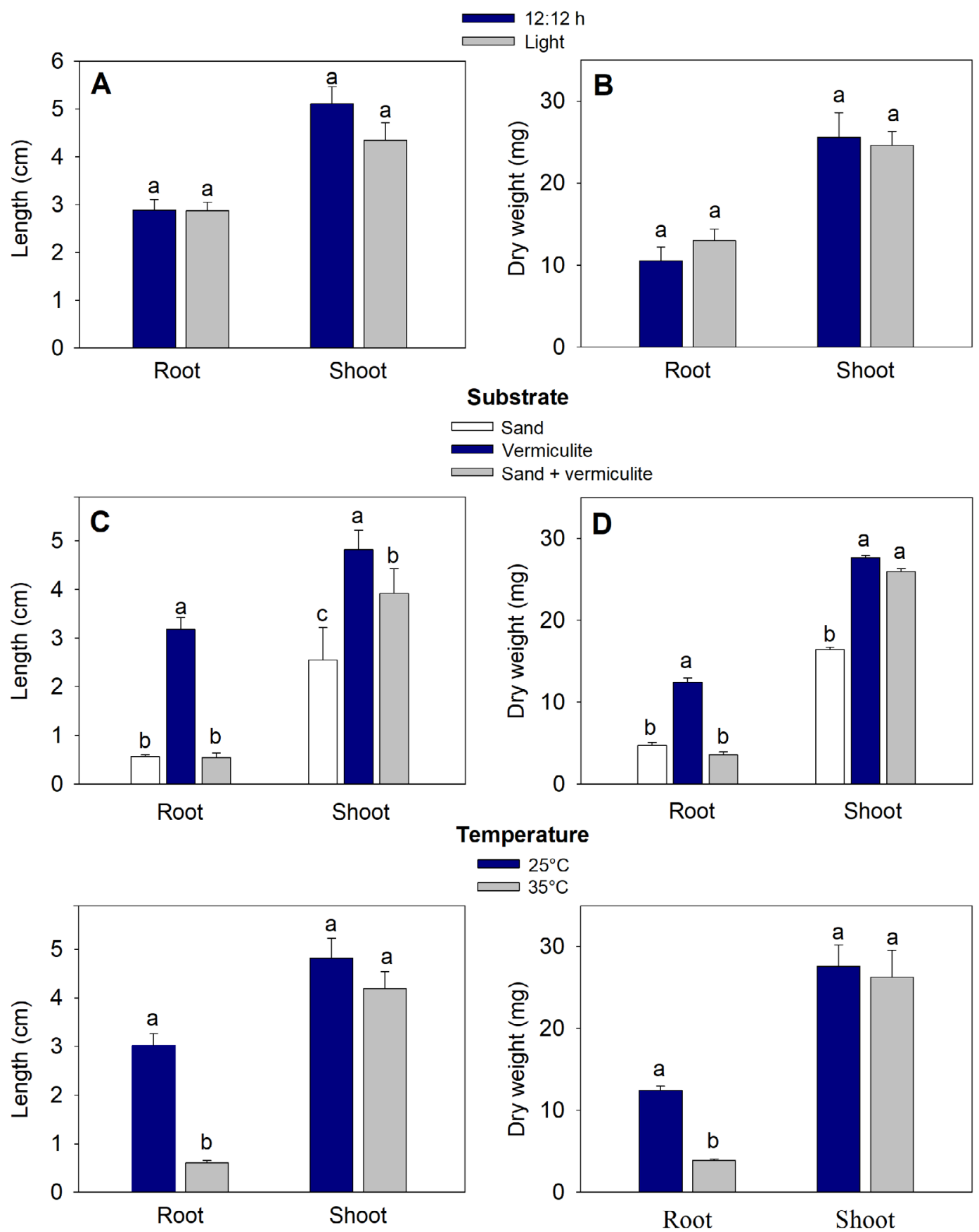

Bars followed by the same letter across light, substrate and temperature conditions, within roots and shoots, do not differ statistically at the $5 \%$ level by Scott-Knott test. Data are mean \pm SE $(n=4)$.

Figure 3. (A and B) Root and shoot length $(\mathrm{cm})$ and dry weight $(\mathrm{mg})$ for seedlings of Garcinia brasiliensis grown under 12:12 h light/dark or 24:0 h light/dark (light). (C and D) Root and shoot length (cm) and dry weight $(\mathrm{mg})$ for seedlings of $G$. brasiliensis grown in sand, sand + vermiculite $(1: 1 ; v: v)$, or vermiculite. (E and F) Root and shoot length $(\mathrm{cm})$ and dry weight $(\mathrm{mg})$ for seedlings of $\mathrm{G}$. brasiliensis grown in vermiculite at $25^{\circ} \mathrm{C}$ or $35^{\circ} \mathrm{C}$. 


\section{CONCLUSIONS}

The propagation of $G$. brasiliensis is improved by planting seeds as soon as they are collected or by storing fruits rather than seeds in the short term. Removing the seed coat and maintaining seeds at $35^{\circ} \mathrm{C}$ are also indicated as they accelerate and enhance seed germination. Finally, cultivating seedlings in vermiculite and at $25{ }^{\circ} \mathrm{C}$ provides an ideal condition for root and shoot growth of this species.

\section{ACKNOWLEDGMENTS}

The authors thank Dr. Fabricio Pereira (Universidade Federal de Alfenas) for his invaluable help in conceiving this study and acknowledge the financial support obtained from CAPES, CNPq and FAPEMIG.

\section{REFERENCES}

ARWA, P.S.; ZERAIK, M.L.; XIMENES, V.F.; FONSECA, L.M.; SILVA, B.V.; SILVA, D.H.S Redox-active biflavonoids from Garcinia brasiliensis as inhibitors of neutrophil oxidative burst and human erythrocyte membrane damage. Journal of Ethnopharmacol, v.174, p.410418, 2015. https://doi:10.1016/j.jep.2015.08.041

BELLINI, C.; PACURAR, D.I.; PERRONE, I. Adventitious roots and lateral roots: similarities and differences. Annual Review of Plant Biology, v.65, p.639-666, 2014. https://doi.org/10.1146/annurev-arplant-050213-035645

BERJAK, P.; PAMMENTER, N.W. Implications of the lack of desiccation tolerance in recalcitrant seeds. Frontiers in Plant Science, v.4, p.478, 2013. https://doi.org/10.3389/fpls.2013.00478

BRANCALION, P.H.S.; NOVEMBRE, A.D.L.C; RODRIGUES, R.R. Temperatura ótima de germinação de sementes de espécies arbóreas brasileiras. Journal of Seed Science, v.32, p.15-21, 2010. https://doi.org/10.1590/S0101-31222010000400002

BRUUN, E.W.; PETERSEN, C.T.; HANSEN, E.; HOLM, J.K.; HAUGGAARD-NIELSEN, H. Biochar amendment to coarse sandy subsoil improves root growth and increases water retention. Soil Use and Management, v.30, p.109-118, 2014. https://doi.org/10.1111/ sum.12102

CARDOSO, A.A.; OBOLARI, A.M.M.; BORGES, E.E.L.; SILVA, C.J.; RODRIGUES, H.S. Environmental factors on seed germination, seedling survival and initial growth of sacha inchi (Plukenetia volubilis L.). Journal of Seed Science, v.37, p.111-116, 2015. https:// doi.org/10.1590/2317-1545v37n2145054

CARDOSO, A.A.; PEREIRA, F.J.; PEREIRA, M.P.; CORRÊA, F.F.; CASTRO, E.M.; SANTOS, B.R. Anatomy of stems, leaves, roots and the embryo of Garcinia brasiliensis Mart.-Clusiaceae. Amazonian Journal of Agricultural and Environmental Sciences, v.56, p.23-29, 2013. http://dx.doi.org/10.4322/rca.2013.076

CORREIA, M.C.R; LIMA, H.A.; SILVA, R.C.P. Caracterização dos frutos, sementes e plântulas de espécies de Clusiaceae das restingas do Rio de Janeiro. Rodriguésia, v.64, p.61-73, 2013. https://doi.org/10.1590/S2175-78602013000100007

FERREIRA, D.F. Sisvar: a computer statistical analysis system. Ciência e Agrotecnologia, v.35, p.1039-1042, 2011. https://doi. org/10.1590/S1413-70542011000600001

GONTIJO, V.S.; SOUZA, T.C.; ROSA, I.A.; SOARES, M.G.; SILVA, M.A.; VILEGAS, W.; VIEGAS-JUNIOR, C.; SANTOS, M.H. Isolation and evaluation of the antioxidant activity of phenolic constituents of the Garcinia brasiliensis epicarp. Food Chemistry, v.132, p.12301235, 2012. https://doi.org/10.1016/j.foodchem.2011.10.110

JOSHI, G.; KUMAR, A.N.A.; GOWDA, B.; SRINIVASA, Y.B. Production of supernumerary plants from seed fragments in Garcinia gummi-gutta: evolutionary implications of mammalian frugivory. Current Science, v.91, p.372-376, 2006. https://www.jstor.org/ stable/24094148

LEAL, D.O.; BENEVIDES, C.R.; SILVA, R.C.P.; SANTIAGO-FERNANDES, L.D.R.; SÁ-HAIAD, B.; LIMA, H.A. Garcinia brasiliensis: insights into reproductive phenology and sexual system in a Neotropical environment. Plant Systematics and Evolution, v.299, p.1577-1585, 2013. https://doi.org/10.1007/s00606-013-0833-7 
LIU, Y.; QIU, Y.; ZHANG, L.; CHEN, J. Dormancy breaking and storage behavior of Garcinia cowa Roxb. (Guttiferae) seeds: implications for ecological function and germplasm conservation. Acta Botanica Sinica, v.47, p.38-49, 2005. https://doi.org/10.1111/j.17447909.2005.00010.x

LUCAS, C.M.; MEKDEÇE, F.; NASCIMENTO, C.M.; HOLANDA, A.S.S.; BRAGA, J.; DIAS, S.; SOUSA, S.; ROSA, P.S.; SUEMITSU, C. Effects of short-term and prolonged saturation on seed germination of Amazonian floodplain forest species. Aquatic Botany, v.99, p.49-55, 2012. https://doi.org/10.1016/j.aquabot.2012.02.004

MAGUIRE, J.D. Speed of germination-aid in selection and evaluation from seeding emergence and vigor. Crop Science, v.2, p.176177, 1962. https://doi.org/10.2135/cropsci1962.0011183X000200020033x

MALIK, S.K.; CHAUDHURY, R.; ABRAHAM, Z. Seed morphology and germination characteristics in three Garcinia species. Seed Science and Technology, v.33, p.595-604, 2005. https://doi.org/10.15258/sst.2005.33.3.07

MOSER, P.; SIMON, M.F.; MEDEIROS, M.B.; GONTIJO, A.B.; COSTA, F.R.C. Interaction between extreme weather events and megadams increases tree mortality and alters functional status of Amazonian forests. Journal of Applied Ecology, v.56, p.2641-2651, 2019. https://doi.org/10.1111/1365-2664.13498

MYERS, N.; MITTERMEIER, R.A.; MITTERMEIER, C.G.; FONSECA, G.A.B.; KENT, J. Biodiversity hotspots for conservation priorities. Nature, v.403, p.853-858, 2000. https://doi.org/10.1038/35002501

NASCIMENTO, E.M.O.; CARVALHO, J.E.U.; MULLER, C.H. Caracterização morfológica da semente e da plântula de bacurizinho (Rheedia acuminata (Ruiz et Pav.) Plachon et Triana - Clusiaceae). Revista Brasileira de Fruticultura, v.24, p.555-558, 2002. https:// ainfo.cnptia.embrapa.br/digital/bitstream/item/101218/1/a55v24n2.pdf

NICHELMANN, L.; BILGER, W. Quantification of light screening by anthocyanins in leaves of Berberis thunbergii. Planta, v.246, p.1069-1082, 2017. https://doi.org/10.1007/s00425-017-2752-2

OLIVEIRA, A.K.M.; NUNES, A.C. Overcoming dormancy in bakupari (Rheedia brasiliensis) seeds. Cientifica, v.41, p.246-250, 2013. http://cientifica.org.br/index.php/cientifica/article/viewFile/396/262

PEREIRA, M.P.; CORRÊA, F.F.; POLO, M.; CASTRO, E.M.; CARDOSO, A.A.; PERERA, F.J. Seed germination of Schinus molle L. (Anacardiaceae) as related to its anatomy and dormancy alleviation. Seed Science Research, v.26, p.351-361, 2016. https://doi. org/10.1017/S0960258516000167

SALES, L.; PEZUK, J.A.; BORGES, K.S.; BRASSESCO, M.S.; SCRIDELI, C.A.; TONE, L.G.; SANTOS, M.H.; IONTA, M.; OLIVEIRA, J.C. Anticancer activity of 7-epiclusianone, a benzophenone from Garcinia brasiliensis, in glioblastoma. BMC Complementary Medicine and Therapies, v.15, p.393, 2015. https://doi.org/10.1186/s12906-015-0911-1

TWEDDLE, J.C.; DICKIE, J.B.; BASKIN, C.C.; BASKIN, J.M. Ecological aspects of seed desiccation sensitivity. Journal of Ecology, v.91, n.2, p.294-304, 2003. https://doi.org/10.1046/j.1365-2745.2003.00760.x

VIANA, W.G.; LANDO, A.P.; SILVA, R.A.D.; COSTA, C.D.D.; VIEIRA, P.H.M.; STEINER, N. Physiological performance of Garcinia gardneriana (Planch. \& Triana) Zappi: a species with recalcitrant and dormant seeds. Journal of Seed Science, v.42, e202042001, 2020. https://doi.org/10.1590/2317-1545v42222357

VITÓRIA, A.P.; ALVES, L.F.; SANTIAGO, L.S. Atlantic forest and leaf traits: an overview. Trees, v.33, p.1535-1547, 2019. https://doi. $\operatorname{org} / 10.1007 / \mathrm{s} 00468-019-01864-\mathrm{Z}$

VOGEL, E.F. Seedlings of dicotyledons. Centre for Agricultural Publishing and Documentation: Wageningen, 1980. https://doi. org/10.1002/fedr.19810920909

ZAMITH, L.R.; SCARANO, F.R. Produção de mudas de espécies das Restingas do município do Rio de Janeiro, RJ, Brasil. Acta Botanica Brasilica, v.18, p.161-176, 2004. https://doi.org/10.1590/S0102-33062004000100014 